\title{
PENGARUH PEMBERIAN AIR KELAPA (HIJAU) MUDA PADA IBU BERSALIN TERHADAP LAMANYA PERSALINAN KALA II DI RUMAH SAKIT UMUM DAERAH Dr. H. ABDUL MOELOEK PROVINSI LAMPUNG TAHUN 2019
}

\author{
Susilawati ${ }^{11}$, Ike Ate Yuviska2) \\ 1 Dosen Program Studi Kebidanan Fakultas Kedokteran Universitas Malahayati Bandar Lampung \\ Email : susilawati_samaly@yahoo.com \\ 2 Dosen Program Studi Kebidanan Fakultas Kedokteran Universitas Malahayati Bandar Lampung \\ Email : ikeyuviska12345@gmail.com
}

\begin{abstract}
Background: Prolonged labor without special complications, can be treated by Non-pharmacological use of Young Green Coconut Water. Besides being easy to find, food and drinks from coconut are also quite popular with the community. It has very good nutritional and has nutritional value. Rich in potassium which can restore stamina immediately. Besides minerals, coconut water also contains sugar. Young green coconut water rich in calcium, potassium, electrolytes, chloride and magnesium that can relieve pain and increase uterine contractions. As the main referral hospital of Lampung Province, Regional General Hospital Dr. H. Abdul Moeloek obtained Medic record data in 2017 for the number of old childbirth events as many as 257 (14\%) from 1895 deliveries.

Objective: To determine the effect of Young Green Coconut Water on second stage of labor duration at Regional General Hospital Dr. H. Abdul Moeloek Lampung Province.

Method: The research design uses true experiments with the Posttest Only Control Group Design approach. Provision of Young Green Coconut Water given to Maternity at the 1st Active Phase (Cervix Dilatation from 4 to $10 \mathrm{~cm}$ ). The population in this study was 66 people on first stage of labor (33 experiments and 33 controls), with purposive sampling technique. Data analysis using independent $T$ test.

Results: Analysis of the average on second stage labor duration for maternal birth given young green coconut water is 26.06 minutes and the average labor for maternal birth that not given young green coconut water is 53.09 minutes. The statistical test results obtained $p$-value $=0,000$ ( $p$-value $<\alpha=0.05$ ) which means that there is an effect of the provision of Young Green Coconut Water on the Length of Second Stage Labor with an average difference of 27.03 minutes.

Conclusion: There is the effect of giving Young Green Coconut Water to the Duration of Second Stage Labor at the Regional General Hospital Dr. H. Abdul Moeloek Lampung Province.
\end{abstract}

Keywords: Young Green Coconut Water, Second Stage of Labor Duration

\section{ABSTRAK}

Latar Belakang : Persalinan lama yang tejadi tanpa komplikasi khusus, dapat ditangani dengan cara Nonfarmakologis menggunakan Air Kelapa (Hijau) Muda selain mudah ditemukan, makanan dan minuman yang berasal dari kelapa juga cukup digemari masyarakat. memiliki khasiat dan nilai gizi yang baik sekali, kaya akan kalium yang dapat memulihkan stamina dengan segera. Selain mineral, air kelapa juga mengandung gula, air kelapa (Hujau) muda yang kaya akan kandungan kalsium, kalium, elektrolit, klorida dan magnesium mampu meredakan nyeri dan mampu meningkatkan kontraksi uterus. Sebagai Rumah Sakit rujukan utama Provinsi Lampung, Rumah Sakit Umum Daerah Dr . H . Abdul Moeloek diperoleh data dari rekam medik tahun 2017 jumlah kejadian Persalinan Lama sebanyak 257 (14 \%) dari 1895 persalinan. 
Tujuan : Mengetahui pengaruh pemberian air kelapa (Hijau) muda pada ibu bersalin terhadap lamanya persalinan Kala II di Rumah Sakit Umum Daerah Dr. H. Abdul Moeloek Provinsi Lampung.

Metode : Rancangan penelitian menggunakan true eksperimen dengan pendekatan Posttest Only Control Grup Design. Pemberian air kelapa (Hijau) muda diberikan pada ibu bersalin kala 1 fase aktif (Pembukaan $4 \mathrm{~s} / \mathrm{d}$ $10 \mathrm{~cm}$ ). Populasi dalam penelitian ini adalah ibu bersalin Kala I berjumlah 66 orang (33 Eksperimen dan 33 kontrol), dengan teknik sampling purposive sampling. Analisis data dengan menggunakan uji T independen.

Hasil : Hasil analisis rata-rata lama persalinan Kala II pada ibu bersalin yang diberikan air kelapa (Hijau) Muda dengan lama persalinan Kala II 26,06 menit, dan rata-rata lama persalinan Kala II yang tidak diberikan Air Kelapa (Hijau) Muda dengan lama persalinan 53.09 menit. Hasil uji statistik didapatkan $p$-value $=0,000$ ( $p$-value $<\alpha=0,05$ ) yang berarti ada pengaruh pemberian Air Kelapa (Hijau) Muda Terhadap Lamanya Persalinan Kala II dengan beda rata - rata 27.03 menit.

Kesimpulan : Ada pengaruh pemberian air kelapa (Hijau) muda terhadap lamanya persalinan kala II di Rumah Sakit Umum Daerah Dr. H. Abdul Moeloek Provinsi Lampung.

Kata Kunci : Air Kelapa (Hijau) Muda, Lama Persalinan Kala II

\section{PENDAHULUAN}

Lamanya persalinan yang terjadi pada kala II merupakan fase terakhir dari suatu persalinan yang berlangsung terlalu lama sehingga timbul gejala gejala seperti dehidrasi, infeksi, kelelahan ibu serta asfiksia dan kematian janin dalam kandungan I Intra Uterin Fetal Death (Saifuddin, 2014).

Beberapa penelitian menunjukkan bahwa faktor penyebab kematian perinatal adalah infeksi, umur ibu, BBLR, riwayat penyakit ibu, ANC tidak lengkap, penghasilan keluarga rendah dan adanya kelainan kongenital, asfiksia, komplikasi kelahiran, partus lama, preeklamsia dan eklamsia (Manuaba, 2012).

Persalinan lama disebabkan karena kontraksi yang tidak adekuat, faktor janin, dan jalan lahir seperti malpresentasi atau malposisi janin belum saatnya melahirkan, masa laten memanjang, inersia uteri, janin terlalu besar, atau panggul ibu sempit, dan anemia (Kasdu, 2013).

Kejadian partus lama dari tahun 2012 sebesar 1,1\% dan di tahun 2013 sebesar 1,8\% (Kemenkes, 2015). Data Dinas Kesehatan Provinsi Lampung kejadian persalinan lama merupakan salah satu faktor penyebab meningkatnya AKI di Provinsi Lampung. Kejadian persalinan lama berkisar antara 1,8\%-2,6\%. Pada tahun 2013 kejadian persalinan lama berkisar antara 3\%-5\%. Data dari Rumah Sakit Dr. H. Abdul Moeloek angka kejadian persalinan lama pada tahun 2012 dari 2.424 persalinan terjadi $121(4,9 \%)$ Kasus.
Sedangkan pada tahun 2013 dari 2.607 persalinan terjadi $151(5,8 \%)$ kasus, tahun 2014 dari 1.892 persalinan terjadi 64 (4,3\%) kasus, tahun 2015 dari 1716 persalinan terjadi $88(5,1 \%)$ kasus dan di tahun 2016 sebanyak 1.728 ibu melahirkan sebanyak $95(5,4 \%)$ kasus (Data Rekam Medis, 2016).

Upaya yang bisa dilakukan ibu hamil agar persalinan berjalan lancar dapat dikendalikan dengan melakukan pemberian asupan nutrisi yang cukup dan adekuat (Achmad, 2008). Karena kurangnya cairan yang masuk menjelang persalinan menyebabkan energi dalam tubuh berkurang yang dapat mengakibatkan power/kekuatan ibu melemah akibatnya tidak mampu meneran.

Kejadian Persalinan Lama tanpa komplikasi khusus, dapat dicegah dengan Cara Nonfarmakologis dengan Mengkonsumsi Air Kelapa (Hijau) Muda pada ibu bersalin, sehingga dapat meminimalisir Persalinan dengan tindakan, Kelapa (Cocos nucifera L.) adalah salah satu tumbuhan yang banyak manfaatnya, khususnya daerah tropis seperti Indonesia. Selain mudah ditemukan, kelapa juga cukup digemari masyarakat. Bagian tumbuhan ini yang banyak kegunaannya adalah air kelapa. Air kelapa diproduksi dalam buah kelapa yang berumur 5 bulan atau lebih, berupa cairan jernih, steril, dan manis rasanya.

Air kelapa memiliki khasiat dan nilai gizi yang baik. Banyak sekali manfaat,air kelapa kaya 
akan kalium yang dapat memulihkan stamina dengan segera. Selain mineral, air kelapa juga mengandung gula (bervariasi antara 1,7 sampai 2,6 persen) dan protein (0,07-0,55 persen). Karena komposisi gizi yang demikian itu, air kelapa berpotensi dijadikan bahan baku produk pangan (Kabelan Kunia, 2007). Air kelapa (Hujau) muda yang kaya akan kandungan kalsium, kalium, elektrolit, klorida dan magnesium mampu meredakan nyeri dan mampu meningkatkan kontraksi uterus (Chapman, 2006)

Rumah Sakit Umum Daerah Dr . H . Abdul Moeloek merupakan Rumah Sakit rujukan utama Provinsi Lampung, dibuktikan dari jumlah persalinan tahun 2017 adalah 1895 (10\%) persalinan dari 18900 persalinan. Berdasarkan hasil Presurvey Data rekam medik Rumah Sakit Umum Daerah Dr. H . Abdul Moeloek Provinsi Lampung tahun 2017 jumlah kejadian Persalinan Lama sebanyak 257 (14 \%) dari 1895 persalinan.

\section{METODE PENELITIAN}

Rancangan penelitian menggunakan true eksperimen dengan pendekatan Posttest Only Control Grup Design (1 kelompok eksperimen dan 1 kelompok kontrol). Pemberian Air Kelapa (Hijau)
Muda diberikan pada ibu Bersalin Kala 1 Fase Aktif (Pembukaan $4 \mathrm{~s} / \mathrm{d} 10 \mathrm{~cm}$ ), diminum sedikit-sedikit minimal $30 \mathrm{ml}-250 \mathrm{ml}$, Kemudian pada persalinan Kala II, diukur lama persalinan menggunakan lembar observasi partograf.Populasi dalam penelitian ini adalah ibu bersalin Kala I Berjumlah 66 orang (33 Kasus dan 33 kontrol), dengan teknik sampling purposive Sampling. Analisis data dengan menggunakan uji $T$ independen. Penelitian Telah dilakukan di Ruang Bersalin Rumah Sakit Umum Daerah Dr. H . Abdul Moeloek Provinsi Lampung bulan, waktu penelitian dilakukan bulan Maret April 2019.

\section{HASIL DAN PEMBAHASAN}

Analisis Univariat

Lamanya Persalinan Kala II Pada Kelompok Ibu Yang Di Berikan Air Kelapa (Hijau) Muda Di Rumah Sakit Dr. H. Abdul Moeloek Provinsi Lampung Tahun 2019

Rata - rata Lama Persalinan Kala II pada ibu bersalin Kala I Yang diberikan Air Kelapa (Hijau) Muda dapat dilihat pada table dibawah.

Berdasarkan Tabel 1 diketahui Rata - rata Lama Persalinan Kala II pada ibu bersalin Kala I Yang diberikan Air Kelapa (Hijau) Muda.

Tabel 1 Rata-Rata Lamanya Persalinan Kala II Pada Kelompok Ibu Yang Di Berikan Air Kelapa (Hijau) Muda Di Rumah Sakit Dr. H. Abdul Moeloek Provinsi Lampung Tahun 2019

\begin{tabular}{ccccccc}
\hline Lama Persalinan & N & Mean & Min & Max & SD & $95 \% \mathrm{Cl}$ \\
\hline Diberikan Air Kelapa (Hijau) Muda & 33 & 26,06 & 10 & 45 & 9.3 & $23.03-29.14$ \\
\hline
\end{tabular}

Lamanya Persalinan Kala II Pada Kelompok Ibu Yang Tidak Di Berikan Air Kelapa (Hijau) Muda Di Rumah Sakit Dr. H. Abdul Moeloek Provinsi Lampung Tahun 2019
Rata - rata Lama Persalinan Kala II pada ibu bersalin Kala I Yang tidak diberikan Air Kelapa (Hijau) Muda dapat dilihat pada table dibawah.

Berdasarkan Tabel 2 diketahui Rata - rata Lama Persalinan Kala II pada ibu bersalin Kala I Yang tidak diberikan Air Kelapa (Hijau) Muda.

Tabel 2 Rata-Rata Lamanya Persalinan Kala II Pada Kelompok Ibu Yang Tidak Di Berikan Air Kelapa (Hijau) Muda Di Rumah Sakit Umum Dr. H. Abdul Moeloek Provinsi Lampung Tahun 2019

\begin{tabular}{ccccccc}
\hline Lama Persalinan & $\mathrm{N}$ & Mean & Min & Max & SD & $95 \% \mathrm{Cl}$ \\
\hline Tidak diberikan Air Kelapa (Hijau) Muda & 33 & 53.09 & 30 & 80 & 12.317 & $48.84-57.34$ \\
\hline
\end{tabular}


Analisis Bivariat

Analisis yang dilakukan untuk mengetahui perbedaan variabel Independent (Konsumsi Air Kelapa (Hijau) Muda) dengan variabel Dependent (waktu persalinan kala II) dengan menggunakan uji statistik t dengan Taraf kesalahan (a) 5\% kemudian diprogram dengan sistem komputer menggunakan program SPSS for windows.

Tabel 3 Pengaruh Pemberian Air Kelapa (Hijau) Muda Terhadap Lamanya Persalinan Kala II di Rumah Sakit Umum Dr. H. Abdul Moeloek Provinsi Lampung Tahun 2019.

\begin{tabular}{lccccc}
\hline \multicolumn{1}{c}{ Lama persalinan } & N & Mean & SD & Beda Mean & P-Value \\
\hline Diberikan Air Kelapa (Hijau) Muda & 33 & 26.06 & 9.334 & \multirow{2}{*}{27.03} & \multirow{2}{*}{0.000} \\
Tidak diberikan Air Kelapa (Hijau) muda & 33 & 53.09 & 12.317 & & \\
\hline
\end{tabular}

\section{PEMBAHASAN}

\section{Analisis Univariat}

Berdasarkan hasil penelitian diketahui ratarata lama persalinan Kala II pada ibu bersalin yang diberikan air kelapa (Hijau) Muda dengan lama persalinan Kala II 26,06 menit, minimal 10 Menit dan max 45 Menit diyakini benar rata-rata lama persalinan Kala II yang diberikan Air Kelapa (Hijau) Muda adalah 23.03 sampai dengan 29.14 menit, proses persalinan kala II lebih cepat dibandingkan ibu bersalin yang tidak diberikan Air Kelapa (Hijau) Muda, dari hasil penelitian rata-rata lama persalinan Kala II yang tidak diberikan Air Kelapa (Hijau) Muda dengan Lama Persalinan 53.09 menit minimal 30 Menit dan max 80 Menit diyakini benar rata-rata Lama Persalinan Kala II yang tidak diberikan Air Kelapa (Hijau) Muda adalah 48.84 sampai dengan 57.34 menit.

Menurut Manuaba (2013), Kala II persalinan dimulai ketika pembukaan serviks sudah lengkap $(10 \mathrm{~cm})$ dan berakhirnya dengan lahirnya bayi. Kala II pada primipara berlangsung selama 1-1,5 jam dan pada multipara 30 menit-1 jam. Persalinan lama disebabkan karena kontraksi yang tidak adekuat, faktor janin, dan jalan lahir seperti malpresentasi atau malposisi janin belum saatnya melahirkan, masa laten memanjang, inersia uteri, janin terlalu besar, atau panggul ibu sempit, dan anemia (Kasdu, 2013). Air kelapa adalah sebuah cairan yang berada di dalam kelapa hijau muda (buah dari pohon kelapa). Air kelapa telah lama menjadi minuman populer di wilayah tropis, khususnya di India, Pesisir Brasil, Asia Tenggara, Kepulauan Pasifik, Afrika, dan Caribbean. Kelapa muda memiliki rasio kadar air dan minyak yang besar. Kelapa disebut tua jika rasio kadar air dan minyaknya optimum untuk menghasilkan santan dalam jumlah yang banyak. Sebaliknya bila buah kelapa terlalu tua, kadar airnya akan semakin berkurang. Pada kondisi tersebut hasil santan yang diperoleh menjadi sedikit Air kelapa tidak hanya berisi air, tetapi juga mengandung nutrisi. Dalam 30 $\mathrm{ml}$ air kelapa terkandung 61 potasium (kalium), 5,45 $\mathrm{mg}$ sodium, dan 1,3 mg gula. Kelapa juga sumber mangan, berisi $60 \%$ mineral sebagai jumlah ideal harian yang direkomendasikan. Kelapa kaya protein dan tinggi kalori. Tetapi kelapa memiliki jenis protein yang membantu untuk membangun otot. Nilai gizi, terutama mineral, komposisi tertingginya dikandung dalam buah kelapa berumur delapan bulan. Kandungan mineral $\mathrm{K}$ (kalium atau potasium) pada air kelapa adalah yang paling banyak, baik pada air kelapa tua maupun air kelapa muda. Mineral kalium yang setinggi ini mampu memulihkan stamina. Mengonsumsi mineral $\mathrm{K}$ juga dapat menurunkan hipertensi, serta membantu mempercepat absorpsi obat-obatan dalam darah. Berdasarkan data penelitian gizi apabila dibandingkan dengan sport drink, air kelapa mengandung sedikit sodium, tetapi memiliki lebih banyak potasium (Vita, 2016).

Menurut Pendapat Peneliti dapat disimpulkan bahwa Kandungan yang ada dalam Air Kelapa (Hijau) Muda dapat mempercepat proses persalinan Kala II, Sehingga dapat mencegah Komplikasi Persalinan Kala II yang dapat terjadi pada ibu dan bayi, baik pada ibu bersalin primigravida maupun multi gravida sehingga dapat menurunkan terjadinya komplikasi pada ibu bersalin. 


\section{Analisis Bivariat}

Pengaruh Pemberian Air Kelapa (Hijau) Muda Terhadap Lamanya Persalinan Kala II di Rumah Sakit Umum Dr. H. Abdul Moeloek Provinsi Lampung Tahun 2019

Hasil uji statistik didapatkan $p$-value $=0,000$ ( $p$-value $<a=0,05$ ) yang berarti ada pengaruh Pemberian Air Kelapa (Hijau) Muda Terhadap Lamanya Persalinan Kala II di Rumah Sakit Umum Daerah Dr. H. Abdul Moeloek Provinsi Lampung Tahun 2019 dengan beda rata - rata 27.03 menit.

Sejalan dengan penelitian yang telah dilakukan oleh Dwy Noer Ainny (2014) untuk mengetahui efektif pemberian air kelapa muda terhadap lama persalinan kala II pada ibu intranatal. Jenis penelitian adalah static group comparison/posttest only control group design dan desain penelitian adalah pre experimental. Populasi yaitu seluruh ibu besalin sebanyak 21 orang dengan sampel sebanyak 20 responden. Teknik sampling yang digunakan dalam penelitian ini adalah probability sampling tipe simple random sampling. Lokasi penelitian ini di BPM Ny. "M" Pungging Mojokerto. Pengumpulan data dilakukan dengan menggunakan lembar observasi. Penelitian ini dilakukan pada tanggal 8-24 Mei 2014 Dilakukan pengolahan data editing, coding, scoring, tabulating. Analisa data menggunakan uji wilcoxon signed rank test dengan program SPSS v.19. Hasil penelitian menunjukkan responden pada kelompok kontrol setengahnya mengalami persalinan patologis (tidak normal) yaitu sebanyak 5 responden (50\%), responden pada kelompok perlakuan hampir seluruh mengalami persalinan fisiologis (normal) yaitu sebanyak 9 responden (90\%). Analisa data menggunakan uji wilcoxon signed rank test diperoleh hasil perhitungan dengan nilai signifikan $=0,046$ sedangkan $a=0,05$. Oleh karena nilai signifikan lebih kecil dari $a=0,05$ maka $\mathrm{HO}$ ditolak $\mathrm{H} 1$ diterima yang artinya pemberian air kelapa muda efektif dalam mengatasi lama kala II pada ibu intranatal. Hasil penelitian menunjukkan bahwa ada pengaruh yang cukup signifikan dari pemberian air kelapa muda terhadap lama persalinan. Disarankan tenaga kesehatan dapat lebih aktif dalam memberikan asuhan sayang ibu untuk memberi asupan nutrisi dan hidrasi/cairan berupa air kelapa muda pada ibu intranatal.

Sejalan dengan Teori bahwa Air kelapa memiliki khasiat dan nilai gizi yang baik. Banyak sekali manfaat,air kelapa kaya akan kalium yang dapat memulihkan stamina dengan segera. Selain mineral, air kelapa juga mengandung gula (bervariasi antara 1,7 sampai 2,6 persen) dan protein (0,07-0,55 persen). Karena komposisi gizi yang demikian itu, air kelapa berpotensi dijadikan bahan baku produk pangan (Kabelan Kunia, 2007). Menurut (Chapman, 2006) Air kelapa (Hujau) muda yang kaya akan kandungan kalsium, kalium, elektrolit, klorida dan magnesium mampu meredakan nyeri dan mampu meningkatkan kontraksi uterus. Air kelapa muda juga mengandung sejumlah mineral, yaitu nitrogen, fosfor, kalium, magnesium, klorin, sulfur, dan besi. Kandungan mineral $\mathrm{K}$ dan nutrisi pada air kelapa adalah yang tertinggi, baik pada air kelapa tua maupun air kelapa muda. Mengonsumsi mineral $\mathrm{K}$ yang tinggi dapat memperkuat his pada saat kontraksi ibu bersalin).

Pemberian air kelapa muda pada ibu intranatal dinilai lebih efisien dibandingkan dengan air mineral biasa, karena air kelapa muda yang mengandung elektrolit, isotonik, mineral dan vitamin lainnya akan menambah kekuatan meneran pada ibu sehingga tidak terjadi persalinan macet atau persalinan lama karena faktor power atau kekuatan ibu (Lestari, 2012). Pemberian air kelapa muda $250 \mathrm{ml}$ pada ibu intranatal dapat menambah asupan nutrisi dan energi pada ibu bersalin, serta dapat mengurangi ketosis pada lbu dalam persalinan tanpa meningkatkan volume lambung. pemenuhan cairan elektrolit dan isotonik dapat meningkatkan kekuatan his kontraksi pada saat bersalin sehingga persalinan menjadi mudah dan tidak berlangsung lama (Ainny, 2014).

Menurut pendapat peneliti pemberian Air Kelapa (Hijau) Muda, merupakan cara Non Farmakologis untuk Mencegah Partus Lama Pada Kala II yang efektif, tanpa efek samping baik bagi ibu maupun bagi bayi, sehingga aman untuk dikonsumsi. Pemanfaat air kelapa muda dianggap mampu meredakan nyeri. Air kelapa muda yang kaya akan kandungan kalsium, kalium, 
elektrolit, klorida, magnesium, riboflavin, dan juga sodium. Sebagai isotonik alami yang kaya mineral dan memiliki elektrolit cair yang sama dengan kandungan cairan di dalam tubuh, tentu saja, air kelapa sangat berguna untuk menghindari dehidrasi dan sangat cepat untuk memulihkan stamina. Ibu bersalin membutuhkan lebih banyak air dibandingkan orang lain yang berada dalam keadaan normal. Dehidrasi selama persalinan akan menyebabkan masalah kesehatan diantaranya sakit kepala, edema, kram, menyebabkan nyeri dan bahkan dapat mengurangi kontraksi uterus yang mengakibatkan persalinan prematur.

\section{KESIMPULAN}

Rata - rata Lama Persalinan Kala II pada Ibu bersalin yang tidak diberikan Air Kelapa (Hijau) Muda adalah 26,06 Menit. Sedangkan rata - rata Lama Persalinan Kala II Pada ibu bersalin yang tidak diberikan Air Kelapa (Hijau) Muda adalah 56,09 Menit.

Hasil uji statistik didapatkan $p$-value $=0,000$ ( $p$-value $<a=0,05)$ yang berarti ada pengaruh Pengaruh Pemberian Air Kelapa (Hijau) Muda Terhadap Lamanya Persalinan Kala II di Rumah Sakit Umum Daerah Dr. H. Abdul Moeloek Provinsi Lampung Tahun 2019 dengan beda rata-rata 27,03.

\section{SARAN}

Diharapkan ibu bersalin dapat memenuhi kebutuhan energi sebelum menjalani proses persalinan Kala I, seperti minum dan makan, atau bisa minum Air Kelapa (Hijau) Muda untuk menambah energi pada saat Persalinan Kala II. Kemudian Diharapakan Para Tenaga kesehatan Khususnya bidan untuk dapat memberikan terapi untuk mempercepat persalinan Kala II dengan cara Non Farmakologis yaitu dengan pemberian Air Kelapa (Hijau) Muda karena tidak ada efek samping bagi ibu dan bayi sehingga aman untuk dikonsumsi dan dapat mengurangi resiko bagi ibu dan janin akibat persalinan Lama. Selanjutnya Diharapkan peneliti lainnya dapat melanjutkan penelitian ini agar dapat lebih menyempurnakan hasil penelitiannya hingga dapat membantu percepanan kala II pada ibu, dengan menambah variabelvariabel lain berhubungan dengan percepatan kala
II.

\section{DAFTAR PUSTAKA}

Ahmad (2008). Metode Penelitian, Bandung : Pustaka Setia

Ainny. (2014). Efektif Pemberian Air Kelapa Muda Terhadap Lama Persalinan Kala II Pada Ibu Intranatal.

Aprina. (2015). Metodelogi penelitian. Lampung

Chapman, ( 2006). Buku Acuan Persalinan Normal, Jakarta : Departemen.

Dinkes Lampung, (2015). Profil Kesehatan Provinsi Lampung

Dinkes Mesuji, (2015). Profil Kesehatan Kabupaten Mesuji

Oxorn, (2010). Ilmu Kebidanan, Patologi dan Fisiologi Persalinan, Jakarta : Andi.

Kasdu, (2013). Asuhan Keperawatan Maternitas, Jakarta : Salemba Medika

Kabelan kunai (2007), Khasiat air kelapa. Pikiran Rakyat https://www.pikiran-rakyat.com/

Lestari, D. Karya Tulis IImiah Penerapan Konsumsi Air Kelapa Muda Terhadap Kemajuan Persalinan Pada Ibu Primigravida Di Klinik Permata Ibu, Tersobo Prembun.

Manuaba IGB. (2013) IImu Kebidanan, Penyakit Kandungan, dan KB. Jakarta:EGC

Mochtar. (2009). Sinopsis Obstetri. Jakarta. EGC

Murti (2010). Desain dan Pengukuran Sampel dalam Penelitian Kesehatan. Yogyakarta : UGM

Saifuddin.(2014). Buku Acuan Nasional Pelayanan Kesehatan Maternal dan Neonatal. Jakarta: Yayasan Bina Pustaka Sarwono Prawiroharjo.

Sulistyawati, Ari. (2012). Buku Ajar Asuhan Kebidanan pada Ibu Bersalin. Edisi I. Yogyakarta : ANDI

Vita, Dian. Kelapa Muda Pelepas Dahaga Sejuta Khasiat. Surabaya: Stomata

Winkjosastro,( 2010). IImu Kandungan. Jakarta : Yayasan Bina Pustaka

Samujizaki (2016). Kelapa hijau dapat menghancurkan batu empedu. http://tanamanbawangmerah.blogspot.com /2015/10/kelapa-hijau-muda-dapat- 
menghancurkan.html

Apamanfaatid (2018). Manfaat minum air kelapa muda. https://apamanfaat.id/manfaat$\underline{\text { minum-air-kelapa-muda }}$
Etik Setianingrum (2013). Partograf. http://midwiferyclass.blogspot.com/2013/01 /partograf-ii.html 